\title{
Transformational Leadership and Organizational Performance: the Mediating Role of Results-Oriented Culture in Vietnamese Public Organizations
}

\author{
Thao Hong Phuong CHAU ${ }^{1 *}$, Truc Dinh LE ${ }^{2}$, Yen Thi TRAN \\ ${ }^{1}$ Faculty of Economics and Business Administration, An Giang University, VNU-HCM, Vietnam. \\ ${ }^{2}$ School of Accounting, University of Economics Ho Chi Minh City, Vietnam \\ ${ }^{3}$ Faculty of Economics and Accounting, Quy Nhon University, Vietnam. \\ ${ }^{*}$ Corresponding author: chpthao@agu.edu.vn
}

\begin{abstract}
Purpose: The paper explores the mediating role of results-oriented culture in the relationship between transformational leadership and the performance of results-oriented culture in Vietnamese public service organizations.

Research motivation: Although there have been studies referring to aspects of culture as mediating transformational leadership and organizational performance in the public sector, however, studies that are concerned with the resultsoriented cultural aspect are still limited. Therefore, the study aims at closing the mentioned gap by examining the effect of tranformational leadership on performance via results-oriented culture.
\end{abstract}

Design, approach and method: We surveyed senior managers, middle managers and chief accountants working at 205 public service organizations in Vietnam. By using structural model analysis (SEM) by SmartPLS 3 software, our study has several important contributions.

Main findings: The findings show that transformational leadership, result-oriented culture are positively associated with organizational performance, and that result-oriented culture is a mediating mechanism that explains how transformational leadership leads to higher performance in public service organizations.

Practical/managerial implications: The research has provided evidence that transformational leadership has a direct and indirect impact on organizational performance through results-oriented culture. These results help public service organizations in Vietnam realize the importance of applying transformational leadership style to lead and build a results-oriented culture.

Keywords: Transformational leadership, results-oriented culture, organizational performance, public sector, new public management, Vietnam.

\section{INTRODUCTION}

Leadership is a popular concept in the field of management science, it is seen as the process of influencing through organized group activities to achieve common goals (Yukl et al., 2019). According to Nusair et al. (2012), leadership is determined based on personal characteristics, behavior, influence on others, accordingly, leadership style models are formed. In the public sector, leadership styles are perceived to be quite diverse, such as Burn (1978) developing transformational leadership theory, Hallinger and Heck (2010) proposing a collaborative leadership model, Tummers and Knies (2016) focus on developing a network governance leadership model. In particular, transformational leadership has remained a popular topic in management research during the last three decades (Pasha et al., 2017). The important role of transformational leadership for achievement patterns has been demonstrated in previous studies. For example, Dvir et al. (2002) suggested that transformational leadership stimulates the development of subordinates. Masa'deh et al. (2016) found that employees perform better when they work under transformational leaders. Mangkunegara \& Miftahuddin (2016) also concluded that transformational leaders have a significant positive influence on the job performance of subordinates. Recently, the research of Nam \& Park (2019) also gave similar results, while Eliyana (2019) concluded that employee's job satisfaction is positively influenced by transformational leadership. Besides, according to the meta-analysis of Wang et al. (2011), transformational leadership has a positive effect on performance at individual, group and organizational levels. Indeed, transformational leadership affects the attitudes of organizational members, creating a goal-oriented spirit (García-Morales et al., 2008).

Research literature also agrees that transformational leadership's impact on organizational performance stems from the organizational cultureshaping function of transformational style (e.g. Parry \& Proctor-Thomson, 2002; Abbasi \& ZamaniMiandashti, 2013; Sun \& Henderson, 2017; Alamir et al., 2019). Transformational leadership does not 
automatically optimize organizational performance, it requires the support of organizational culture (Parry et al., 2002). Specifically, transformational leaders create a culture of learning that supports creativity, change, and adaptation to new conditions (Abbasi \& ZamaniMiandashti, 2013). In addition, Sun \& Henderson (2017) recognizes the mediating role of collaborative culture. Another aspect of organizational culture suggested in the study by Alamir et al. (2019) is equity, where perceived equity by employees is promoted by transformational leaders, thereby increasing job satisfaction. Through these studies, the role of organizational culture in the relationship between transformational leadership and performance has been recognized.

Although some authors argue that the impact of leadership is more limit in the public sector than in the private sector (Nusair et al., 2012). However, there is no denying the essential function of the leader for the optimal deployment of resources in public organizations; and of course also requires the intervention of the organizational culture (Parry \& Proctor-Thomson, 2002). Arguing about how transformational leadership benefits the organization through the formation of organizational culture, Bass and Avolio (1997) argue that transformational leadership creates a favorable operating environment where helps employees always strive to exceed expectations, feel attached and encouraged, accept innovation, thereby improving personal and organizational performance. In the public sector, a results-oriented culture is viewed as a culture that emphasizes accountability, commitment to the organization, and recognition of individual achievements from the perspective of the NPM philosophy (Verbeeten \& Speklé, 2015). Therefore, there is reason to believe that adopting transformational leadership in the public sector has the potential to strengthen a results-oriented culture, which in turn results in better organizational performance. As stated, although there have been studies referring to aspects of culture as mediating transformational leadership and organizational performance in the public sector (e.g. Abbasi \& Zamani-Miandashti, 2013; Sun \& Henderson, 2017), however, studies that are concerned with the outcome-oriented cultural aspect are still limited.

This study was conducted to close the research gap as stated, specifically to propose and test the structural model between the concepts of transformational leadership, results-oriented culture and organizational performance in the context of public service organizations in Vietnam. Like other developing countries, Vietnam is still trying to reform the public sector to meet the new requirements of the market economy. However, public service organizations in Vietnam still have many weaknesses in governance, quality and efficiency of public services, besides, the quality and labor productivity of the staff is still low (Central Executive Committee, 2017). Therefore, the recommendations proposed from the results of this study will be a useful source for public sector governance implications, enriching the academic literature on the relevant topic. In addition, the research limitations discussed will serve as a basis for future research directions.

\section{LITERATURE REVIEW AND DEVELOPMENT HYPOTHESES}

\subsection{Transformational leadership and results- oriented culture}

Organizational culture is often formed from the creation of the organization's founders and is passed on to successor leaders. Over time, organizational culture forms shared values, guided assumptions, and is constrained by the leadership's personal beliefs (Bass $\&$ Avolio, 1994). Indeed, in the process of information processing of the organization, leaders gradually reflect their values and beliefs, which govern the entire operation of the organization (Nguyen \& Mohamed, 2011). Similarly, Denison (1990) claimed that management behaviors support principles of the culture. Leaders inspire and help create the kind of organizational culture that adapts to change. Kotter and Heskett (1992) define successful leaders as those who continuously communicate their vision, stimulate middle managers to get to work and effectively manage the organization. These are the traits that suit transformational leadership.

There have been many studies referring to the relationship between leadership and organizatinal culture. Accordingly, leadership is seen as an important predictor of organizatinal culture (e.g. Ayman \& Korabik, 2010; Taormina, 2008; Tipu et al., 2012; Li et al., 2018). According to Ogbonna and Harris (2000), culture is an organizational variable which can be manipulated, it depends on the skill and ability of the leader. In addition, the research literature has acknowledged that leadership and organizational culture have a relationship with each other during organizational change (Nguyen \& Mohamed, 2011). Transformational leadership has a strong influence on shaping organizational culture (e.g. Bass \& Avolio, 1994). More specifically, transformational leadership drives organizational change by forming a strategic vision for the organization and motivating all employees to strive for the necessary goals (Nusair et al., 1990). While a results-oriented culture also emphasizes the importance of individual efforts to accomplish organizational goals (Chang \& Lin, 2019). Organizations with a results-oriented culture are adaptable to unexpected, complex situations and willing to accept challenges (Hofstede et al., 1990). With this type of culture, individuals in the organization are willing to innovate and face difficulties (Chang \& Lin, 2015). From these arguments, we propose the following hypothesis: 
Hypothesis 1 (H1): Transformational leadership positively affects results-oriented culture.

\subsection{Results-oriented culture and organizational performance}

Research literature has agreed that organizational culture is one of the antecedents of performance. Furthermore, different cultures exert different influences on aspects of performance (Yesil $\&$ Kaya, 2013). The trend of public sector reform under the NPM philosophy requires public institutions to strengthen performance-based governance (Nitzlt et al, 2019). To do this, public institutions need to first replace the traditional bureaucratic culture (e.g. focus on adherence to rigid rules) by a results-oriented culture, to reduce dependence on procedures and regulations (Arellano-Gault \& Lepore, 2011; Verbeeten \& Speklé, 2015). When an organization creates a results-oriented culture, all employees have a strong commitment to achieving goals and managers are willing to take responsibility for the results achieved (OECD, 1994). Besides, Tran et al. (2020) also emphasized that results-oriented culture helps organizations focus more on outputs with the expectation of improving performance.

The positive impact of a results-oriented culture on organizational performance has been confirmed in previous studies (e.g. Garnett et al., 2008; Verbeeten \& Speklé, 2015; Tran et al., 2020). Typically in the public sector, Verbeeten and Speklé (2015) conclude that a results-oriented culture has a positive impact on the performance of public organizations in the Netherlands. And the study by Tran et al (2020) gives similar results when testing in the Vietnamese public sector. In addition, Nitzlt et al (2019) further expands on this relationship. The authors found a positive moderating influence of components of NPM-oriented culture on public sector performance in Italy, including results-oriented culture. Thus, both theory and results from empirical studies support the view that the higher the results-oriented culture, the higher the performance. Therefore, the hypothesis about the relationship between these two concepts is as follows:

Hypothesis 2 (H2): Results-oriented culture positively affects organizational performance.

\subsection{Transformational leadership and organizational performance}

In any organization, the function of a leader is to promote and improve performance, to achieve this, leaders must encourage and support employees to find ideas for work improvement (Arif \& Akram, 2018). Leaders are directly or indirectly involved in activities to achieve organizational goals, so they are seen as key players in determining organizational performance (Brewer \& Selden, 2000). This means that the personal characteristics and behavior of the leader influence the effectiveness of the organization. Indeed, the leader's function for the organization is reflected through leadership style, in which the influence of transformational leadership style on performance is the most discussed (Van Wart, 2014; Pasha et al., 2017; Elmarsy \& Bakri, 2019). Accordingly, transformational leadership style has a positive effect on performance at both individual, team and organizational levels (Trottier, Van Wart, \& Wang, 2008; Vigoda-Gadot \& Beeri, 2011). Transformational leaders can control the effects of uncertainty by imparting a continuous improvement mindset to their subordinates and help reduce conflicts within the organization (Mokgolo et al., 2012), thereby improving the ability of individuals and organizations to achieve their goals.

In the public sector, the characteristic of transformational leaders is added in the aspect of assisting employees to implement creative solutions to complex problems, thus improving the efficiency and quality of public services (Vera \& Crossan, 2004). Evidence from the academic literature recognizes the importance of transformational leadership style in the public sector (Van Slyke \& Alexander, 2006; Oberfield, 2014). It is particularly useful as an effective governance mechanism in a public sector environment (Wright \& Pandey, 2010). In addition, Paarlberg and Lavigna (2010) emphasize that transformational leadership is a value-based leadership strategy that is particularly relevant to the public sector. It helps to improve the visibility of individuals' work goals, thereby contributing to the overall improvement of the organization. Moreover, the public sector is characterized by service to the community, so a condition for good results is that employees need to prioritize the collective interest instead of focusing on individual interests. And this is driven by transformational leadership. Therefore, we hypothesize the influence of transformational leadership on the performance of public organizations as follows:

$\begin{array}{rrrr}\text { Hypothesis } 3 & \text { (H3): } & \text { Transformational } \\ \text { leadership positively } & \text { affects } & \text { organizational }\end{array}$ performance.

\subsection{Mediating role of result-oriented culture}

Literature have proven that transformational leadership not only has a direct effect on performance, but also has an indirect influence through intermediary mechanisms (Wang et al., 2011; Alrowwad, et al., 2017; Sun \& Hendersen, 2017; Arif \& Akram, 2018). As in the study of García et al. (2008), transformational leaders stimulate innovation and accumulate knowledge for work, thus it will promote efficiency and organizational output. Likewise, Arif and Akram (2018) argue that organizational innovation has a mediating role in the relationship between transformational leadership and organizational performance. In addition, Katou (2015) emphasizes that the intermediary mechanism in the relationship between transformational leadership and organizational performance is quite complex, it is three serially mediating, including organizational justice, 
organizational trust and employee reactions. In the public sector, when researching in public schools, Sun and Henderson (2017) confirmed the indirect influence of transformational leadership on organizational performance through three components of organizational processes (e.g. collaborative culture, performance information use, parental engagement).

On the mediating role of organizational culture, Tabassi et al. (2017) suggested that transformational leadership style has a strong impact on the creation of environment and working conditions, for example, interpersonal communication, individual contribution, level of competition and conflict. organizational conflict, accountability, and interpersonal relationships. And these elements directly drive organizational performance. Leaders inspire and help create the kind of organizational culture that adapts to change. A leader's success is in consistently communicating their vision, creating a challenging environment, and encouraging subordinates to get to work, and these are all characteristics of transformational leadership (Kotter \& Heskett, 1992). Combining these views, we predict the intermediate relationship in the following hypothesis:

Hypothesis 4 (H4): Results-oriented culture mediates the relationship between transformational leadership and organizational performance.

\section{METHODS}

\subsection{Samples and procedures}

The public service organizations in Vietnam were established in accordance with the law by competent authorities to provide and serve the state management of public services. Currently, public service organizations are in the process of renovating their organizational and management systems to improve operational quality and efficiency according to Resolution no. 19-NQ/TW (Central Executive Committee, 2017). Specifically, the overall goal of this resolution is to streamline the structure, improve governance, enhance autonomy, and maintain the dominant role in the public service market. Data for this study were collected from senior, middle and chief accountants in public service organizations. The data collection instrument is a well-structured questionnaire prepared in advance, each answer sheet represents information for a unit. To ensure that the information on the survey was understandable and relevant, the questionnaire was pre-tested by eight managers of the units. Then, the survey form is completed and sent directly, or via email and social networks to the survey subjects. The survey period was conducted from August 2020 to December 2020, a total of 224 responses out of a total of 483 questionnaires were sent. In which, there are 205 valid answer sheets and used for analysis by SmartPLS3 software.

The linear structural model in our study was analyzed with the partial least squares technique (PLS-
SEM), which is a standard tool for analyzing complex relationships in social science research (Hair et al., 2017). PLS-SEM does not require normally distributed data and can deal with small sample sizes (Hair et al, 2019). In this study, the number of questionnaires collected was less than 250, so PLS-SEM is appropriate and useful in this situation.

Among the respondents, $84.8 \%$ of the sample is the head or deputy head of the unit, the rest is the chief accountant, with the working experience of all the respondents over 6 years. These characteristics ensure the quality and reliability of the information collected. Because these respondents are key players in the organization, they have enough knowledge and experience on issues related to leadership, organizational culture and performance. Classified by field, the majority are education and health service providers with $73.2 \%$, the rest are other fields such as culture, sports, tourism, media, etc. This reflects the reality of the sectoral structure of public service organizations in Vietnam (General Statistics Office, 2018). Therefore, the data collected is sufficiently representative of the population, supporting the generalizability of the research results.

\subsection{Measures}

Three latent concepts in the research model are measured by many observed variables, which have been tested and confirmed in previous studies (see . The responses to the observed variables were graded on a 5-point scale. Transformational leadership (TL) is measured by 5 observed variables, inherited from House's (1998) scale, which is a commonly used scale in public governance studies (e.g., Wright et al., 2012; Kroll \& Vogel, 2014; Campbell, 2018). Accordingly, respondents were asked to rate the transformational leadership skills of senior managers in their units, the level of agreement for statements ranging from 1 (strongly disagree) to 5 (strongly disagree). Resultsoriented culture (CUL) is a concept developed under the OECD-NPM doctrine (Verbeeten \& Speklé, 2015). This scale captures the extent to which respondents agree with four statements related to accountability, performance, management's commitment to goal achievement, and recognition of individual contributions. The degree of agreement with these statements is graded 5 points as transformational leadership variable. For organizational performance, we use perceptual measurement instead of based on built-in criteria. Because, when measuring organizational performance in the public sector, it is more appropriate to use self-assessment reports based on personal feelings than archival data (Kim, 2010; Giauque et al., 2013; Pollanen et al., 2017). The commonly used organizational assessment in public sector research is based on the scale developed by Van de Ven and Ferry (1980) (e.g. Verbeeteen, 2008; Speklé \& Verbeeten, 2014; Nitzt et al., 2019, Tran et al., 2020). Specifically, organizational performance (PER) is measured by seven observed variables, which 
comprehensively reflect both quantitative and qualitative aspects of operational performance. Accordingly, the respondents will rate their personal feelings about the performance of their units compared to similar units and are ranked on 5 levels, from 1 (far below average) to 5 (far above average).

\section{RESULTS}

\subsection{Testing the measurement model}

The measurement model estimates the relationship between the observed variables and the structure to be measured (Mahama \& Cheng, 2013). The requirements that need to be met to ensure the appropriateness of the measurement model include reliability, convergence value and discriminant value of the scale (Hair et al., 2017). The details of the measurement model evaluation results are presented in Table 1.

Table1: Evaluation of the construct measurements

\begin{tabular}{|c|c|c|c|c|c|c|}
\hline Variables & Min & Max & Mean & $\mathrm{SD}$ & $\begin{array}{c}\text { Outer } \\
\text { loadings }\end{array}$ & t-value \\
\hline \multicolumn{7}{|l|}{ Transformational leadership $(\mathrm{CB}=0.786 ; \mathrm{CR}=0.853$; $\mathrm{AVE}=0.538)$} \\
\hline TL1 My leader clearly articulates his/her vision of the future & 1 & 5 & 3.93 & 0.76 & 0.710 & 17.079 \\
\hline TL2 My leader leads by setting a good example & 1 & 5 & 3.88 & 0.77 & 0.797 & 22.205 \\
\hline $\begin{array}{l}\text { TL3 My leader challenges me to think about old problems in } \\
\text { new ways }\end{array}$ & 1 & 5 & 3.63 & 0.91 & 0.681 & 11.657 \\
\hline $\begin{array}{l}\text { TL4 My leader says things that make employees proud to be part } \\
\text { of the organization }\end{array}$ & 1 & 5 & 3.62 & 0.94 & 0.749 & 14.830 \\
\hline $\begin{array}{l}\text { TL5 My leader has a clear sense of where our organization } \\
\text { should be in five years }\end{array}$ & 1 & 5 & 3.79 & 0.94 & 0.727 & 16.974 \\
\hline \multicolumn{7}{|l|}{ Results-oriented culture $(\mathrm{CB}=0.785 ; \mathrm{CR}=0.861 ; \mathrm{AVE}=0.609)$} \\
\hline $\begin{array}{l}\text { CUL1 Higher management of my organization is strongly } \\
\text { committed to achieving the formulated objectives }\end{array}$ & 1 & 5 & 4.05 & 0.83 & 0.752 & 14.162 \\
\hline $\begin{array}{l}\text { CUL2 Managers in my organization are being held responsible } \\
\text { for the results they achieve }\end{array}$ & 2 & 5 & 4.01 & 0.72 & 0.859 & 37.250 \\
\hline $\begin{array}{l}\text { CUL3 Managers in my organization are confronted when they do } \\
\text { not succeed in realizing their targets }\end{array}$ & 2 & 5 & 3.96 & 0.83 & 0.762 & 17.624 \\
\hline $\begin{array}{l}\text { CUL4 Employees in my organization receive recognition when } \\
\text { they help to achieve the objectives of my organization }\end{array}$ & 1 & 5 & 4.05 & 0.83 & 0.743 & 17.662 \\
\hline \multicolumn{7}{|l|}{ Organizational performance $(\mathrm{CB}=0.916 ; \mathrm{CR}=0.932 ; \mathrm{AVE}=0.665)$} \\
\hline PER1 The quantity or amount of work produced & 1 & 5 & 3.95 & 0.82 & 0.717 & 11.445 \\
\hline PER2 The quality or accuracy of work produced & 1 & 5 & 3.99 & 0.78 & 0.845 & 28.080 \\
\hline PER3 The number of innovations or new ideas by the unit & 1 & 5 & 3.69 & 0.84 & 0.732 & 18.025 \\
\hline PER4 The reputation of 'work excellence.' & 1 & 5 & 4.18 & 0.74 & 0.843 & 33.116 \\
\hline PER5 Attainment of unit production or service goals & 1 & 5 & 4.08 & 0.76 & 0.866 & 38.892 \\
\hline PER6 The efficiency of unit operations & 2 & 5 & 4.06 & 0.75 & 0.837 & 42.378 \\
\hline PER7 The morale of unit personnel & 1 & 5 & 4.01 & 0.89 & 0.817 & 33.471 \\
\hline
\end{tabular}

Notes: CB: Cronbach's Alpha; CR: Composite reliability; AVE: Average variance extracted; SD: Standard deviation

The reliability of the observed variables can be accepted when the latent concept explains more than $50 \%$ of the variance of each of these variables (Hair et al., 2019), and the minimum threshold for the external load factor is 0.5 (Hulland, 1999). Intrinsically consistent reliability of the scale is assessed by the Cronbach Alpha index (CB) or composite reliability (CR). However, using CR criteria produces a higher confidence value than CB (Hair et al., 2019). For the scale to be reliable, the $\mathrm{CR}$ should have a value between 0.70 and 0.90 (Hair et al., 2017). According to the results in Table 1, we confirm that the reliability of the scale of concepts in this study is satisfactory. Because the outer loadings index of all observed variables has values from 0.681 to 0.866 and the tvalue is greater than 2.54 . Furthermore, the CR values of the structures ranged from 0.853 to 0.932 , satisfying the criterion proposed by Hair et al. (2019).
Average extracted variance (AVE) is the criterion to evaluate the convergent value of the scale, the recommended acceptable threshold is 0.5 (Hair et al., 2019). According to the analysis results in Table 1, we found that all scales met the requirements of convergence value with the lowest AVE value of 0.538 . Next, the discriminant value is also evaluated by the heterotrait-monotrait ratio (HTMT), which is a superior evaluation criterion compared to the crossload coefficient and the Fornell Larcker criterion (Henseler et al., 2015). As presented in Table 2, the highest value of the HTMT ratio in our analysis report was 0.640 , lower than the recommended value of 0.85 (Henseler et al., 2015). Thus, the scales used to measure latent structures in this study have good discriminant validity. 
Table 2: Construct means, standard deviations, and correlations

\begin{tabular}{|c|c|c|c|}
\hline Construct & $\begin{array}{c}\text { Transformational } \\
\text { leadership }\end{array}$ & $\begin{array}{c}\text { Results-oriented } \\
\text { culture }\end{array}$ & $\begin{array}{c}\text { Organizational } \\
\text { performance }\end{array}$ \\
\hline Transformational leadership & $0.734^{1}$ & & \\
\hline Results-oriented culture & $0.511^{*}$ & $0.780^{1}$ & \\
\hline & $0.640^{2}$ & & $0.815^{1}$ \\
\hline Organizational performance & $0.430^{*}$ & $0.510^{*}$ & 3.993 \\
\hline Mean & $0.482^{2}$ & $0.588^{2}$ & 0.808 \\
\hline Standard deviation & 3.769 & 4.021 & 0.778 \\
\hline
\end{tabular}

Notes: ${ }^{1}$ Square root of AVE and, ${ }^{2}$ HTMT ratio, *: Correlation is significant at the $1 \%$ level (two-tailed t-test) Next, we present the structural model estimation results in Table 3. In which, the adjusted $\mathrm{R}^{2}$ value represents

\subsection{Testing the structural model}

After the measurement model is satisfactory, we evaluate the results of the structural model to estimate the explanatory level of the path coefficients (Hair et al., 2019). Firstly, we check the multicollinearity phenomenon using the VIF coefficient to ensure that this is not the cause of the biased regression results (Hair et al., 2019). The research results show that the VIF values of the variables range from 1.43 to 3.36 , which is lower than the threshold for multicollinearity of 5.0 (Hair et al., 2017). This confirms that multicollinearity is not a serious problem in this study. the explanatory level of the independent variables for the dependent variables, respectively 0.257 (resultsoriented culture) and 0.292 (organizational performance). The accepted minimum adjusted $\mathrm{R}^{2}$ value as recommended by Hair et al. (2019) is 0.1 . Therefore, the theoretical model that we propose is consistent with the collected experimental data.

Consistent with the prediction in hypothesis $\mathrm{H} 1$, transformational leadership has a significant positive effect on results-oriented culture. The analysis results show that the path coefficient of this direct relationship is statistically significant at $1 \%(\beta=0.511, \mathrm{t}=9.184)$.

Table 3: PLS effects model

\begin{tabular}{|c|l|c|c|c|c|}
\hline Hypothesis & \multicolumn{1}{|c|}{ Independent variable } & Results-oriented culture & Oragnizational Performance \\
\hline Direct effects & $\beta$ & t-value & $\beta$ & t-value \\
\hline H1 & Transformational leadership & 0.511 & $9.184^{*}$ & & \\
\hline H2 & Results-oriented culture & & & 0.393 & $4.951^{*}$ \\
\hline H3 & Transformational leadership & & & 0.229 & $3.403^{*}$ \\
\hline Indirect effect & $\begin{array}{l}\text { Transformational leadership -> Results-oriented cuture -> Organizational performance: } \beta= \\
\text { H4 } \\
0.201 ; t-v a l u e=4.284^{*}\end{array}$ \\
\hline Adjusted R ${ }^{2}$
\end{tabular}

Note: *: Correlation is significant at the $1 \%$ (2-tailed t-test)

This once again confirms the role of leadership in predicting organizational culture, not only in the private sector (Ogbonna \& Harris, 2000; Pradhan et al., 2017) but also in the sector public sector. This result shows that leaders with transformational style pose challenges and inspire subordinates, encourage employees to think innovatively and take responsibility for results (Kao, 2015), are consistent with a resultoriented culture.

Hypothesis $\mathrm{H} 2$ proposes a positive influence of results-oriented culture on organizational performance in Vietnamese public service organizations. The results in Table 2 confirmed this hypothesis $(\beta=0.393, \mathrm{t}=$ 4.951) with statistical significance of $1 \%$. This result reinforces the assumptions of NPM theory (Hood, 1995), the key to improving public sector performance is the formation of a results-oriented culture, instead of just focusing on controlling inputs as traditional bureaucratic culture that already exists in the public sector (OECD, 2002). This relationship is also confirmed in previous studies by Verbeeten \& Speklé (2015); Nitzl et al. (2019); Tran et al (2020). Therefore, the emergence of a results-oriented culture in public institutions to lead to higher results is inevitable.

According to the test results, hypothesis $\mathrm{H} 3$ is accepted with a significance level of $1 \%(\beta=0.229, \mathrm{t}=$ 3.403). This means that a leader with a transformational style enhances organizational performance. This result is not surprising because previous studies have shown that individual and organizational performance is positively influenced by transformational leadership styles (e.g. Dvir et al. 2002; Judge \& Piccolo, 2004; Piccolo \& Colquitt, 2006). In the public sector, this result is consistent with the study of Elmasry and Bakri (2019), although using a different transformational leadership scale. Transformational leaders communicate the mission, motivate employees and promote their engagement 
(Bass, 1985) as well as cohesion in the top leadership team, leading to higher effective and organizational performance (Colbert et al., 2008).

Finally, the indirect influence of transformational leadership on organizatinal performance through results-oriented culture in public service organizations is suggested in hypothesis $\mathrm{H} 4$. The authors used the bootrap technique to distribute the sample and test the role of the intermediate variable as suggested by Hair et al., (2017). The analysis results in Table 2 support this hypothesis with a statistical significance level of $1 \%(\beta=0.201 ; \mathrm{t}=4.284)$. As mentioned before, hypotheses $\mathrm{H} 1, \mathrm{H} 2$ and $\mathrm{H} 3$ have been accepted, so the results-oriented culture plays a part mediating role in the relationship between transformational leadership and organizatinal performance. This implies that public entities operating under transformational leadership will accelerate the reform process towards improving performance through creating a results-oriented cultural environment. This evidence also further supports transformational leadership theory in the following way. Transformational leaders contribute to organizational success by inspiring employees to increase focus on the importance of the results the organization needs to achieve. Thereby, promoting internal motivation of employees, making them prioritize organizational benefits instead of focusing on personal interests (Moynihan et al., 2013). In general, transformational leadership promotes cultures that benefit the organization (e.g. the innovation culture of Parry and Proctor-Thomson (2002), the collaborative culture of Sun \& Henderson (2017)). In which, resultsoriented culture is a type of culture that should be promoted in the public sector according to NPM theory (Hood, 1995).

\section{DISCUSSION AND CONCLUSION}

\subsection{Theoretical contributions}

Evidence from this study extends to the literature on the relationship between transformational leadership, organizational culture and performance, especially in the public sector. Although, previous studies have considered cultural factors as a mediating mechanism to further explain the influence of transformational leadership on aspects of outcomes at the individual or organizational level (e.g. Jaskyte, 2004; Sun \& Henderson, 2017), however, the resultoriented culture suggested by the NPM framework seems to be rarely mentioned. Therefore, the important contribution of this study is to provide additional evidence confirming the partial mediating role of results-oriented culture in the relationship between transformational leadership and performance of public organizations. Accordingly, if managers adopt a transformational leadership style, it will create standards of commitment to task performance, accountability, and increase employee motivation by recognizing their contributions. As a result, the performance of public organizations will be improved.

Furthermore, transformational leadership promoting the formation of results-oriented culture in organizations is the next important outcome of this study. This influence can be explained in the view of Bass and Avolio (1994), where organizational culture and leadership interact and motivate each other. The development of organizational culture is largely influenced by its leaders, conversely, organizational culture also has a significant influence on leadership ability. More specifically, transformational leaders shape a work environment in which the leader encourages employees to commit to the organization's mission, communicates a new vision, and prepares them for organizational improvement (Bass \& Avolio, 1994). Although the influence of leadership on organizational culture is much discussed, empirical evidence on this topic is still limited (Abdullah et al., 2015). Therefore, the results of this study contribute to enriching the research literature by adding empirical evidence on the influence of transformational leadership on the results-oriented culture, especially in public service organizations in Vietnam.

In addition, this study also found the effect of results-oriented culture on the performance of public organizations, consistent with the research results of Verbeeten and Speklé (2015) and Tran et al. (2020). This reinforces the argument of NPM theory that public organizations should promote increased accountability and strong commitment to organizational goals (Verbeeten \& Speklé, 2015). This study is even more meaningful when conducted in a developing country because the research related to public sector reform under NPM in these countries is still limited (Tran et al., 2020). Furthermore, Heady (2001) finds that one of the major challenges in public administration in developing countries is the lack of results orientation. The public sector in many countries seems to care only about short-term achievements and not to the long-term goals of the program, resulting in short-term goals being achieved but may have a negative impact on long-term results (Heady, 2001). Strengthening a results-oriented culture is therefore a necessary condition for the long-term performance goals of the public sector.

\subsection{Managerial contributions}

Firstly, this study has confirmed the important role of transformational leadership in the reform process to improve the performance of public organizations in Vietnam. With the starting point of a centrally subsidized economy, the process of public sector reform in Vietnam is likely to face resistance from officials, because they were attached to the values of the economy the old way (Trong Tuan, 2017). Therefore, the first important step is to change the mindset of officials in the public sector, then the role of the leader should be promoted. Public leaders need to 
apply the principles of transformational leadership to model organizational behaviors, leading to a new culture for public entities in which employees accept innovation for the overall development of the organization. This is especially relevant in the situation of public service organizations in Vietnam. Because, according to Resolution no. 19, one of the renovation goals to improve the quality and performance of Vietnam's public service organizations is the need to apply modern management methods, and transformational leaders have the ability to diffuse innovation in public organizations (Nusair et al., 2012), to adapt to the uncertainty of the working environment (Lim \& Ployhart, 2004). The public service organizations should strengthen transformational leadership training for current leaders. At the same time, public service organizations should prioritize recruiting and appointing leaders with characteristics of transformational style to run the unit.

Second, Marcoulodes \& Heck (1993) confirmed that the operating environment of the organization has a significant influence on the attitudes and perceptions of employees, thereby affecting the performance of the organization. Combined with the results of this study, we suggest that managers in Vietnam's public service organizations should pay attention to creating and spreading results-oriented culture in their organizations. To accomplish this, it requires managers to show determination when performing tasks, always be a good role model, take responsibility for work results, and recognize employees' contributions based on results. These activities not only improve organizational performance, but also create job satisfaction and motivate employees to achieve higher job performance (Jin et al., 2016). In addition, strengthening the results-oriented culture also creates benefits for the organization in another aspect, that is, it requires transparency and financial accountability (Tran et al., 2020; Anh Vu et al, 2021). This is very necessary given the fact that public service organizations in Vietnam still use most of the state budget (Tran et al., 2020). Moreover, during the transition, the public sector in Vietnam still faces problems of bureaucracy, red tap and corruption, especially lack of accountability (Anh Vu, 2021). Thus the transparency and accountability requirements of a results-oriented culture would be helpful in addressing these issues.

Third, the results of the indirect influence of transformative leadership on organizational performance through the results-oriented culture suggest that besides transformationalism, managers in the public sector need to translate it into action. It means that leaders need to build a results-oriented culture. Indeed, leadership and organizational culture are two precursors of performance (Nam \& Park, 2019), where the relationship between transformative leadership and performance is mediated by organizational culture (Ogbonna \& Harris, 2000;
Xenikou \& Simosi, 2006). The purpose of the public sector's existence is to serve the needs of the citizens, not for the sake of profit, so implementation strategies aim to maximize efficiency and performance. Public agencies in Vietnam are no exception, always striving to improve their ability to meet public services with increasing quality. Therefore, in the training and development project of public managers, there should be courses on transformational leadership theory and the characteristics of a result-oriented culture. More generally, to improve public sector performance, leaders and managers in the public sector need to demonstrate a strategic vision, enabling employees to innovate the way they work. In addition, they set an example by being determined to achieve organizational goals, taking responsibility for work results, and having appropriate incentives for employees.

\subsection{Limitations and directions for further research}

Besides the theoretical and practical contributions as presented, this study also has certain limitations. Firstly, in terms of concepts, transformational leadership in this study is considered as a unidirectional concept, while if considered comprehensively, this concept is multi-directional with four components such as building by (Bass \& Avolio, 1994). In addition, the performance of public organizations is subjectively measured based on perception, although there are advantages, it also lacks objectivity and authenticity compared to measurements based on quantitative criteria (Meier \& Brudney, 2002). To overcome this limitation, further research needs to consider in more detail the components of transformational leadership, because each component of this concept can exert different effects on overall performance (Deinert et al. al., 2015), combining selfreported and archival data to measure organizational performance (e.g. Verbeeten \& Speklé, 2015) to reduce bias due to subjective perceptions of respondents. At that time, researchers can explore more about the influence mechanism of transformational leadership on organizational performance and will have more basis to propose in detail the implications of public governance. Secondly, organizational culture is a broad concept (Nitzt et al., 2019) but this study only considers the outcome-oriented culture aspect. Meanwhile, the influence of transformational leadership on organizational performance is likely to be influenced by other cultures such as innovation culture, collaborative culture (e.g. Xenikou, 2006; Sun \& Henderson, 2017). Therefore, future studies may explore other aspects of organizational culture. Thirdly, the data to test this model is collected in public service organizations, a significant part of the public sector in Vietnam. However, in order to improve the generalizability of the research results, it would be better to add data from a variety of public institutions. Finally, we found that other mediating mechanisms may be involved in the relationship between transformational leadership and organizational 
performance. For example, public service motivation (Paarlberg \& Lavigna, 2010), and using performance information (Moynihan et al., 2013) can be further research directions for researchers. Another interesting thing is organizational culture can be the moderator of the relationship between transformational leadership and organizational performance (Al-Shibami et al., 2019), which are directions that can expand the research.

\section{REFERENCES}

[1] Abbasi, E., \& Zamani-Miandashti, N. (2013). The role of transformational leadership, organizational culture and organizational learning in improving the performance of Iranian agricultural faculties. Higher Education, 66(4), 505-519.

[2] Abdullah, N. H., Shamsuddin, A., \& Wahab, E. (2015). Does organizational culture mediate the relationship between transformational leadership and organizational commitment? International Journal of Organizational Leadership, 4, 18-32.

[3] Alamir, I., Ayoubi, R. M., Massoud, H., \& Al Hallak, L. (2019). Transformational leadership, organizational justice and organizational outcomes: A study from the higher education sector in Syria. Leadership \& Organization Development Journal.

[4] Alrowwad, A. A., Obeidat, B. Y., Tarhini, A., \& Aqqad, N. (2017). The impact of transformational leadership on organizational performance via the mediating role of corporate social responsibility: A structural equation modeling approach. International Business Research, 10(1), 199-221.

[5] Al-Shibami, A. H., Alateibi, N., Nusari, M., Ameen, A., Khalifa, G. S., \& Bhaumik, A. (2019). Impact of organizational culture on transformational leadership and organizational performance. International Journal of Recent Technology and Engineering, 8, 653-664.

[6] Anh Vu, T., Plimmer, G., Berman, E., \& Ha, P. N. (2021). Performance management in the Vietnam public sector: The role of institution, traditional culture and leadership. International Journal of Public Administration, 1-15.

[7] Arellano-Gault, D., \& Lepore, W. (2011). Transparency reforms in the public sector: Beyond the new economics of organization. Organization Studies, 32, 1029-1050.

[8] Arif, S., \& Akram, A. (2018). Transformational leadership and organizational performance: the mediating role of organizational innovation. SEISENSE Journal of Management, 1(3), 59-75.

[9] Ayman, R., \& Korabik, K. (2010). Leadership: Why gender and culture matter. American Psychologist, 65, 157-170.

[10] Bass, B. M., \& Avolio, B. J. (1994). Transformational leadership and organizational culture. The International Journal of Public Administration, 17(3-4), 541-554.

[11] Bass, B. M., \& Avolio, B. J. (1997). Concepts of leadership. Leadership: Understanding the dynamics of power and influence in organizations, 323.

[12] Bass, B.M. (1985) Leadership and Performance Beyond Expectation. New York: The Free Press.

[13] Brewer, G. A., \& Selden, S. C. (2000). Why elephants gallop: Assessing and predicting organizational performance in federal agencies. Journal of Public Administration Research and Theory, 10(4), 685-712.

[14] Burns, J. (1978), Leadership, Harper \& Row, New York, NY.

[15] Campbell, J. W. (2018). Efficiency, incentives, and transformational leadership: Understanding collaboration preferences in the public sector. Public Performance \& Management Review, 41(2), 277-299.

[16] Central Executive Committee. (2017). Resolution No. 19-NQ/TW on continuing to renovate the organization and management system, improving the quality and performance of public service organizations. Hanoi.

[17] Chang, C. L. H., \& Lin, T. C. (2019). The relationship between organisational culture and knowledge management culture. International Journal of Information Systems and Change Management, 11(2), 128-156.

[18] Colbert, A. E., Kristof-Brown, A., Bradley, B. H., \& Barrick, M. R. (2008). CEO transformational leadership: The role of goal importance congruence in top management teams. Academy of Management Journal, 51, 81-96.

[19] Deinert, A., Homan, A. C., Boer, D., Voelpel, S. C., \& Gutermann, D. (2015). Transformational leadership sub-dimensions and their link to leaders' personality and performance. The Leadership Quarterly, 26(6), 1095-1120.

[20] Denison, D. R. (1990). Corporate culture and organizational effectiveness. New York: Wiley.

[21] Dvir, T., Eden, D., Avolio, B. J., \& Shamir, B. (2002). Impact of transformational leadership on follower development and performance: A field experiment. Academy of Management Journal, 45(4), 735-744.

[22] Eliyana, A., \& Ma'arif, S. (2019). Job satisfaction and organizational commitment effect in the transformational leadership towards employee performance. European Research on Management and Business Economics, 25(3), 144-150.

[23] Elmasry, M. O., \& Bakri, N. (2019). Behaviors of transformational leadership in promoting good governance at the Palestinian public sector. International Journal of Organizational Leadership, 8, 1-12.

[24] García-Morales, V. J., Lloréns-Montes, F. J., \& Verdú-Jover, A. J. (2008). The effects of 
transformational leadership on organizational performance through knowledge and innovation. British Journal of Management, 19(4), 299-319.

[25] Garnett, J. L., Marlowe, J., \& Pandey, S. K. (2008). Penetrating the performance predicament: Communication as a mediator or moderator of organizational culture's impact on public organizational performance. Public Administration Review, 68, 266-281.

[26] General Statistics Office. (2018). Statistical yearbook 2017. Statistics Publishing House, Hanoi, Vietnam.

[27] George, B., Van de Walle, S., \& Hammerschmid, G. (2019). Institutions or contingencies? A cross-country analysis of management tool use by public sector executives. Public Administration Review, 79(3), 330-342.

[28] Giauque, D., Anderfuhren-Biget, S., \& Varone, F. (2013). HRM practices, intrinsic motivators, and organizational performance in the public sector. Public Personnel Management, 42(2), 123-150.

[29] Government. (2021), Decree no. 60/2021/ND$\mathrm{CP}$ on regulations on financial autonomy mechanism of public service organizations. Hanoi.

[30] Hair, J. F., Hult, G. T. M., Ringle, C., \& Sarstedt, M. (2017). A primer on partial least squares structural equation modeling (PLS-SEM) (Second ed.). Sage Publications.

[31] Hair, J. F., Risher, J. J., Sarstedt, M., \& Ringle, C. M. (2019). When to use and how to report the results of PLS-SEM. European Business Review.

[32] Hallinger, P., \& Heck, R. H. (2010). Leadership for learning: Does collaborative leadership make a difference in school improvement? Educational Management Administration \& Leadership, 38(6), 654-678.

[33] Heady, F. (2001). Public administration: A comparative perspective (6th ed.). New York: Marcel Dekker.

[34] Henseler, J., Ringle, C. M., \& Sarstedt, M. (2015). A new criterion for assessing discriminant validity in variance-based structural equation modeling. Journal of the Academy of Marketing Science, 43, 115-135.

[35] Hofstede, G., Neijen, B., Ohayv, D.D. and Sander, G. (1990) 'Measuring organizational cultures: a qualitative and quantitative study across twenty cases', Administrative Science Quarterly, Vol. 35, No. 2, pp.286-316.

[36] Hood, C. (1995). The "new public management" in the 1980s: Variations on a theme. Accounting, Organizations and Society, 20(23), 93-109.

[37] House Robert, J. (1998). Appendix: Measures and assessments for the charismatic leadership approach: Scales, latent constructs, loadings, Cronbach alphas, interclass correlations. Fred,
Dansereau, Yammarino Francis J, editors. Leadership: The multiple level approaches contemporary and alternative. London, UK: JAI.

[38] Hulland, J. S. (1999). The effects of countryof-brand and brand name on product evaluation and consideration: A cross-country comparison. Journal of International Consumer Marketing, 11(1), 23-40. http://dx.doi.org/10.1300/J046v11n01_03

[39] Jaskyte, K. (2004). Transformational leadership, organizational culture, and innovativeness in nonprofit organizations. Nonprofit Management and Leadership, 15(2), 153-168.

[40] Jin, M., McDonald, B., \& Park, J. (2016). Followership and job satisfaction in the public sector: The moderating role of perceived supervisor support and performance-oriented culture. International Journal of Public Sector Management.

[41] Judge, T.A., Piccolo, R.F., 2004. Transformational and transactional leadership: a metaanalytic test of their relative validity. J. Appl. Psychol. 89 (5), 755-768.

[42] Kao, R.H. (2015), "A study on the relationship between transformational leadership and organizational climate: using HLM to analyse context effects of police organization", Global Advanced Research Journal of Management and Business Studies, Vol. 4 No. 3, pp. 87-115

[43] Katou, A. A. (2015). Transformational leadership and organisational performance: Three serially mediating mechanisms. Employee Relations. [44] Kim, J. (2010). Strategic human resource practices: Introducing alternatives for organizational performance improvement in the public sector. Public Administration Review, 70(1), 38-49.

[45] Kotter, J. P., \& Heskett, J. L. (1992). Corporate culture and performance. New York: Free Press.

[46] Kroll, A., \& Vogel, D. (2014). The PSMleadership fit: A model of performance information use. Public Administration, 92(4), 974-991.

[47] Li, W., Bhutto, T. A., Nasiri, A. R., Shaikh, H. A., \& Samo, F. A. (2018). Organizational innovation: the role of leadership and organizational culture. International Journal of Public Leadership.

[48] Lim, B. -C., \& Ployhart, R. E. (2004). Transformational leadership: Relations to the fivefactor model and team performance in typical and maximum contexts. Journal of Applied Psychology, 89, 610-621. http://dx.doi.org/10.1037/00219010.89.4.610.

[49] Mahama, H., and M. M. Cheng. 2013. "The Effect of Managers' Enabling Perceptions on Costing System Use, Psychological Empowerment, and Task Performance." Behavioral Research in Accounting 25 (1): 89-114. doi:10.2308/bria-50333.

[50] Mangkunegara, A. P., \& Miftahuddin. (2016). The effect of transformational leadership and job satisfaction on employee performance. Universal Journal of Management, 4(4), 189-195 
[51] Marcoulides, G. A., \& Heck, R. H. (1993). Organizational culture and performance: Proposing and testing a model. Organization science, 4(2), 209225.

[52] Masa'deh, R., Obeidat, B.Y., \& Tarhini, A. (2016). A Jordanian empirical study of the associations among transformational leadership, transactional leadership, knowledge sharing, job performance, and firm performance: A structural equation modelling approach. Journal of Management Development, 35, 681-705. https://doi.org/10.1108/JMD-09-2015-0134

[53] Meier, K. J., \& Brudney, J. L. (2002). Applied statistics for public administration. Harcourt Press.

[54] Mokgolo, M. M., Mokgolo, P., \& Modiba, M. (2012). Transformational leadership in the South African public service after the April 2009 National Elections. SA Journal of Human Resource Management, 10(1), 1-9.

[55] Moynihan, D. P., Pandey, S. K., \& Wright, B. E. (2013). Transformational leadership in the public sector: Empirical evidence of its effects. In Public administration reformation (pp. 101-118). Routledge. [56] Nam, K. A., \& Park, S. (2019). Factors influencing job performance: organizational learning culture, cultural intelligence, and transformational leadership. Performance

Improvement Quarterly, 32(2), 137-158.

[57] Nguyen, H. N., \& Mohamed, S. (2011). Leadership behaviors, organizational culture and knowledge management practices: An empirical investigation. Journal of management development.

[58] Nitzl, C., Sicilia, M., \& Steccolini, I. (2019). Exploring the links between different performance information uses, NPM cultural orientation, and organizational performance in the public sector. Public Management Review, 21(5), 686-710.

[59] Nusair, N., Ababneh, R., \& Bae, Y. K. (2012). The impact of transformational leadership style on innovation as perceived by public employees in Jordan. International Journal of Commerce and Management.

[60] Oberfield, Z. W. (2014). Public management in time: A longitudinal examination of the full range of leadership theory. Journal of Public Administration Research and Theory, 24(2), 407-429. [61] OECD (2002). (Perrin, B.) Implementing the vision: addressing challenges to results-focused management and budgeting.

[62] Ogbonna, E., \& Harris, L. C. (2000). Leadership style, organizational culture and performance: empirical evidence from UK companies. International Journal of Human Resource Management, 11(4), 766-788.

[63] Paarlberg, L. E., \& Lavigna, B. (2010). Transformational leadership and public service motivation: Driving individual and organizational performance. Public Administration Review, 70(5), $710-718$
[64] Parry, K., \& Proctor-Thomson, S. (2002). Leadership, culture and performance: The case of the New Zealand public sector. Journal of Change Management, 3(4), 376-399.

[65] Pasha, O., Poister, T. H., Wright, B. E., \& Thomas, J. C. (2017). Transformational leadership and mission valence of employees: The varying effects by organizational level. Public Performance \& Management Review, 40(4), 722-740.

[66] Piccolo, R.F., Colquitt, J.A., 2006. Transformational leadership and job behaviors: the mediating role of core job characteristics. Acad. Manage. J. 49 (2), 327-340.

[67] Pollanen, R., Abdel-Maksoud, A., Elbanna, S., \& Mahama, H. (2017). Relationships between strategic performance measures, strategic decisionmaking, and organizational performance: empirical evidence from Canadian public organizations. Public Management Review, 19(5), 725-746.

[68] Pradhan, R. K., Panda, M., \& Jena, L. K. (2017). Transformational leadership and psychological empowerment: The mediating effect of organizational culture in Indian retail industry. Journal of Enterprise Information Management.

[69] Spekle, R. F., \& Verbeeten, F. H. (2014). The use of performance measurement systems in the public sector: Effects on performance. Management Accounting Research, 25(2), 131-146.

[70] Sun, R., \& Henderson, A. C. (2017). Transformational leadership and organizational processes: Influencing public performance. Public Administration Review, 77(4), 554-565.

[71] Tabassi, A.A., Roufechaei, K.M., Abu Bakar, A.H. and Yusof, N. (2017) 'Linking team condition and team performance: a transformational leadership approach', Project Management Journal, Vol. 48, No. 2, pp.22-38.

[72] Taormina, R. J. (2008). Interrelating leadership behaviors, organizational socialization, and organizational culture. Leadership \& Organization Development Journal.

[73] Tran, T.Y., Nguyen, N. P., \& Nguyen, L. D. (2020). Results-oriented Culture and Organizational Performance: The Mediating Role of Financial Accountability in Public Sector Organizations in Vietnam. International Journal of Public Administration, 1-16.

[74] Tipu, S. A. A., Ryan, J. C., \& Fantazy, K. A. (2012). Transformational leadership in Pakistan: An examination of the relationship of transformational leadership to organizational culture and innovation propensity. Journal of Management \& Organization, 18(4), 461-480.

[75] Trong Tuan, L. (2017). Reform in public organizations: The roles of ambidextrous leadership and moderating mechanisms. Public Management Review, 19(4), 518-541.

[76] Trottier, T., Van Wart, M., \& Wang, X. (2008). Examining the nature and significance of 
leadership in government organizations. Public Administration Review, 68(2), 319-333.

[77] Tummers, L., \& Knies, E. (2016). Measuring public leadership: Developing scales for four key public leadership roles. Public Administration, 94(2), 433-451.

[78] Van de Ven, A. H., \& Ferry, D. L. (1980). Measuring and assessing organizations. John Wiley \& Sons.

[79] Van Slyke, D. M., \& Alexander, R. W. (2006). Public service leadership: Opportunities for clarity and coherence. The American Review of Public Administration, 36(4), 362-374.

[80] Van Wart, M. (2014). Dynamics of leadership in public service: Theory and practice. Routledge.

[81] Vera, D., \& Crossan, M. (2004). Strategic leadership and organizational learning. Academy of Management Review, 29(2), 222-240.

[82] Verbeeten, F. H. (2008). Performance management practices in public sector organizations: Impact on performance. Accounting, Auditing \& Accountability Journal, 21(3), 427-454. https://doi.org/10.1108/09513570810863996

[83] Verbeeten, F. H., \& Speklé, R. F. (2015). Management control, results-oriented culture and public sector performance: Empirical evidence on new public management. Organization Studies, 36(7), 953-978.

[84] Vigoda-Gadot, E., \& Beeri, I. (2011). Changeoriented organizational citizenship behavior in public administration: The power of leadership and the cost of organizational politics. Journal of Public Administration Research and Theory, 22(3), 573-596. [85] Wang, G., Oh, I. S., Courtright, S. H., \& Colbert, A. E. (2011). Transformational leadership and performance across criteria and levels: A metaanalytic review of 25 years of research. Group \& organization management, 36(2), 223-270.

[86] Wright, B. E., Moynihan, D. P., \& Pandey, S. K. (2012). Pulling the levers: Transformational leadership, public service motivation, and mission valence. Public Administration Review, 72(2), 206215.

[87] Xenikou, A., \& Simosi, M. (2006). Organizational culture and transformational leadership as predictors of business unit performance. Journal of Managerial Psychology.

[88] Yesil, S., \& Kaya, A. (2013). The effect of organizational culture on firm financial performance: Evidence from a developing country. Procedia Social and Behavioral Sciences, 81, 428-437.

[89] Yukl, G., Mahsud, R., Prussia, G., \& Hassan, S. (2019). Effectiveness of broad and specific leadership behaviors. Personnel Review.

[90] Zammuto, R. F., \& Krakower, J. Y. (1991). Quantitative and qualitative studies of organizational culture. Research in Organizational Change and Development, 5, 83-114. 